\title{
Test post-weaning duration for performance, feed intake and feed efficiency in Nellore cattle ${ }^{1}$
}

\author{
André Michel de Castilhos ${ }^{2}$, Renata Helena Branco ${ }^{3}$, Alexander George Razook ${ }^{3,4}$, \\ Sarah Figueiredo Martins Bonilha ${ }^{3}$, Maria Eugênia Zerlotti Mercadante ${ }^{3,4}$, Leopoldo \\ Andrade de Figueiredo ${ }^{3}$
}

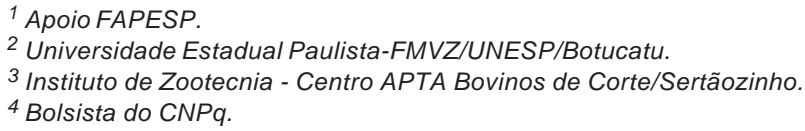

ABSTRACT - This study was conducted to determine optimum test duration for measuring performance, feed intake and feed efficiency. Sixty young Nellore bulls were submitted to feeding performance test and fed in individual pens to determine feed intake and performance over 112 days. Body weight was determined every 28 days, after fasting of water and feed for 16 hours. Changes in variance, relative variance and Pearson and Spearman correlations among data from shortened test periods (28, 56 and 84 days) and full test period (112 days) were used to determine optimum test duration. Test duration for average daily gain, dry matter intake, feed:gain ratio and residual feed intake could be shortened to $84,28,84$ and 84 days, respectively, without reducing significantly the reliability of measurements for animals fed in individual pens.

Key Words: beef cattle, feeding performance test, residual feed intake

\section{Duração do período de avaliação pós-desmame para medidas de desempenho, consumo e eficiência alimentar em bovinos da raça Nelore}

\footnotetext{
RESUMO - O objetivo neste estudo foi determinar o melhor período de avaliação para medidas de desempenho, consumo e eficiência alimentar. Durante 112 dias, 60 machos da raça Nelore, recém-desmamados, submetidos à prova de ganho de peso, foram alimentados em baias individuais para determinação do consumo alimentar e do desempenho. O peso corporal dos animais foi determinado a cada 28 dias, depois de jejum de 16 horas de líquidos e sólidos. As alterações na variância, variância relativa e correlações de Pearson e Spearman entre os dados dos períodos de avaliação reduzidos (28, 56 e 84 dias) e período total (112 dias) foram usados para determinar a melhor duração do período de avaliação. A duração do período de avaliação para ganho médio diário, consumo de matéria seca, conversão alimentar e consumo alimentar residual pode ser reduzida para 84 28, 84 e 84 dias, respectivamente, pois tal redução não diminui significativamente a confiabilidade das avaliações em animais alimentados em baias individuais.
}

Palavras-chave: bovinos de corte, consumo alimentar residual, prova de ganho de peso

\section{Introduction}

Feed intake data has been included in selection projects to improve feed efficiency and to reduce costs with feeding. There is evidence for genetic variation in the nutrient usage measured in beef cattle (Machado Neto et al., 2010) and this indicates that selection for animals that consume less for the same gain and weight results in divergent calf crops for the same trait (Herd et al., 2003).

Including new selection criteria should be always conducted aiming to obtain accuracy results by evaluating the selection effects on main economic components of beef cattle, which are compatible with Brazilian conditions, so their results can be used as indicators of the selection power and genetic gain potential of Brazilian beef cattle herd (Razook \& Mercadante, 2007).

Measuring individual feed intake is much more expensive than measuring only weight gain, what is a limitation for applying selection for feed efficiency traits. Accuracy measurements of individual feed intake, growth and feed efficiency in animals require a test over a period of time. Management and feeding costs can be reduced if an appropriate test duration would be identified to reduce the costs of measurement without compromising data accuracy and reliability (Archer et al., 1997). 
Changes on methods used to evaluate performance traits of beef cattle selected during the last 30 years in Centro APTA Bovinos de Corte, from Instituto de Zootecnia of São Paulo state, Brazil, should be revaluated for its own validation to meet and incorporate the recent goals of beef cattle research. Results can improve the feeding performance test in order to evaluate the incorporation in the raking not only performance but also feed efficiency traits. The objectives of this study were to determine optimum test duration for measuring performance, feed intake and feed efficiency and to examine the impacts on data reliability caused by an eventual period reduction for 28, 56 and 84 days compared to full test period (112 days).

\section{Material and Methods}

The experiment was conducted at Centro APTA Bovinos de Corte, Instituto de Zootecnia, Sertãozinho, São Paulo state, Brazil. This region is characterized by a tropical humid climate $\left(21^{\circ} 10^{\prime}, 48^{\circ} 05^{\prime}\right)$, with annual average temperature of $24^{\circ} \mathrm{C}$ and average annual precipitation of $1888 \mathrm{~mm}$

Animal were evaluated according to feeding performance test rules described by Razook et al. (1997). Sixty Nellore males, after weaning, were evaluated on feeding performance test performed in 2007 from Control Nellore (NeC; $n=19)$ and Selection Nellore (NeS; $n=41)$ herds, with initial body weight and age of $170 \pm 27.8 \mathrm{~kg}$ and $210 \pm 14$ days, respectively. Weighings were performed every $28 \mathrm{~d}$ after fasting (feed and water) for 16 hours.

Diet comprised Brachiaria brizantha hay (44.9\%), ground corn (31.9\%), cottonseed meal (21.5\%) and mineral salt $(1.7 \%)$ and was formulated to contain $11 \%$ of crude protein and $65 \%$ of total digestible nutrients, in dry matter basis, according to NRC (1996) recommendations. Experimental diets were provided twice a day (8:00 a.m. and 03:00 p.m.), with free access to feed and water. Individual voluntary intake was calculated by the difference between offered feed and leftovers refusals. Leftovers refusals were daily collected, weighed, sampled in $10 \%$ of its weight to be analyzed for dry matter according to standard procedures (AOAC, 1995).

Average daily gain ( $\mathrm{kg} /$ day), dry matter intake (kg/day), feed:gain ratio (intake/gain) and residual feed intake (kg/day) were the traits individually calculated for animals in each test periods evaluated (28, 56, 84 and 112 days).

Individual daily weight gain and average metabolic body weight were obtained through the linear regression of weighings as a function of test duration. Feed:gain ratio was calculated by the ratio of dry matter intake and daily weight gain. Dry matter intake was estimated from a regression (Koch et al., 1963) model of daily feed intake in relation to average metabolic body weight (averageBW = (finalBW + initial BW)/2 $)^{0.75}$ ) and to daily weight gain, as follows: estimated DMI $=-1.301015+2.300828 \times \mathrm{DMI}+$ $0.091755 \times \mathrm{BW}^{0.75}\left(\mathrm{r}^{2}=0.885, \mathrm{SEM}=0.292\right)$. Residual feed intake was calculated as the difference between animal's actual feed intake and its predicted feed intake.

Four criteria (Wang et al., 2006) were used to determine the optimal test duration in this study. These were variance $\left(\mathrm{s}^{2}\right)$ reduction for each trait and test period, relative variance $\left(\mathrm{s}^{2} \%\right)$, defined as the percentage difference between the variance obtained from the previous measurement and the current measurement divided by the variance obtained from the first measurement (28 days) $\left(\mathrm{s}^{2} \%=\left(\left(\right.\right.\right.$ previous $\mathrm{s}^{2}-$ current $\left.\left.\left.s^{2}\right) / s^{2} 28\right) \times 100\right)$, which was used as an additional criterion to assess the variance changes. In addition, Pearson and Spearman rank correlations over shortened (28, 56 and 84 days) and full (112 days) test periods also provides a measure for a reliable decision. Coefficients of Pearson and Spearman rank correlation were performed utilizing the procedure CORR (SAS, 1999), following the instruction PARTIAL for the traits herd and sire.

Variance components and coefficients of correlation among shortened and total periods were the criteria used to determine optimum test duration (Table 1). The Spearman rank correlation in one that provides very reliable informations for predicting the ideal test period, because the analysis is able to make full use of the positions in different periods (Steel et al., 1997).

Standardized weight index at 378 days (IP378) and feeding performance test index (IPGP) were calculated for 3 test periods (56, 84 and 112 days), with the respective ranking, according to the method previously described. Average daily gain of 112 days of test used in the formula to calculated IP378 e IPGP indexes was replaced by the daily weight gain of the respective test period (56 and 84 days), maintaining 168 days to calculate the standardized weight index at 378 days of age, for further comparison with full test period (112 days). Animals with index higher than a standard deviation above the mean of the experimental group were classified as Elite and those that did not reach this value were named "not selected" (NS). The Elite class is the selection criterion for choosing sires to be used in the original herd, following the breed standard required by the Associação Brasileira de Criadores de Zebu - ABCZ.

Total dry matter intake of animals during the test periods was calculated to evaluate the amount of feed consumed in each period, including adaptation phase (two 28-days 
Table 1 - Criteria adopted to determine the optimum test duration for performance and feed efficiency

\begin{tabular}{|c|c|c|c|c|}
\hline Criterion & Specie & Measure & Total period & Recommended period \\
\hline $\begin{array}{l}\text { Spearman correlations } \\
\text { Coefficient of determination }\left(\mathrm{r}^{2}\right) \\
\text { Coefficient of variation (CV\%) }\end{array}$ & $\begin{array}{l}\text { Beef } \\
\text { Cattle }\end{array}$ & $\begin{array}{l}\text { Brown et al. (1991) } \\
\text { Average daily gain } \\
\text { Feed:gain ratio }\end{array}$ & 140 & $\begin{array}{l}112 \\
112 \\
112\end{array}$ \\
\hline $\begin{array}{l}\left.\text { Variance components ( } \mathrm{s}^{2} \text { and } \mathrm{s}^{2 \%}\right) \\
\text { Phenotypic and genetic correlations } \\
\text { Heritability }\left(\mathrm{h}^{2}\right) \\
\text { Selection efficiency }\end{array}$ & $\begin{array}{l}\text { Beef } \\
\text { Cattle }\end{array}$ & $\begin{array}{l}\text { Archer et al. (1997) } \\
\text { Dry matter intake } \\
\text { Average daily gain } \\
\text { Feed:gain ratio } \\
\text { Residual feed intake }\end{array}$ & 119 & $\begin{array}{l}35 \\
70 \\
70 \\
70\end{array}$ \\
\hline $\begin{array}{l}\text { Variance components }\left(s^{2} \text { and } s^{2} \%\right) \\
\text { Phenotypic and genetic correlations } \\
\text { Heritability }\left(h^{2}\right)\end{array}$ & Sheep & $\begin{array}{c}\text { Snowder \& Van Vleck (2002) } \\
\text { Average daily gain }\end{array}$ & 98 & 56 \\
\hline $\begin{array}{l}\text { Variance components ( } \mathrm{s}^{2} \text { and } \mathrm{s}^{2} \% \text { ) } \\
\text { Pearson and Spearman correlations }\end{array}$ & $\begin{array}{l}\text { Beef } \\
\text { Cattle }\end{array}$ & $\begin{array}{l}\text { Wang et al. (2006) } \\
\text { Dry matter intake } \\
\text { Average daily gain } \\
\text { Feed:gain ratio } \\
\text { Residual feed intake }\end{array}$ & 91 & $\begin{array}{l}35 \\
63 \\
42 \\
63\end{array}$ \\
\hline $\begin{array}{l}\text { Variance components ( } \mathrm{s}^{2} \text { and } \mathrm{s}^{2} \% \text { ) } \\
\text { Phenotypic correlations }\end{array}$ & Swine & $\begin{array}{l}\text { Arthur et al. (2008) } \\
\text { Dry matter intake } \\
\text { Average daily gain } \\
\text { Feed:gain ratio } \\
\text { Residual feed intake }\end{array}$ & 56 & $\begin{array}{l}28 \\
35 \\
35 \\
35\end{array}$ \\
\hline
\end{tabular}

periods). The amount consumed in each phase was calculated in relation to the total test period (168 days) (adaptation period followed by four 28-days periods).

Dataset were generated and analyzed using the MIXED procedure of SAS (1999), as a repeated measures analysis, to allow heterogeneous variances and correlations among different time intervals on test (Wang et al., 2006). The model included herd, duration of test period and herd $\times$ test period interaction as fixed effects and sire within herd as random effect.

\section{Results and Discussion}

The fluctuation in the variance remained stable after 56 days of measurement, with the exception of dry matter intake variance, which increased with the increase of the test period (Figure 1).

Pearson and Spearman correlations (Figures 2 and 3) reached $0.80(P<0.001)$ after 56-days and $0.90(P<0.001)$ after 84-days period of test for all evaluated traits.

Variance for daily weight gain reduced $44.90 \%$ comparing the 28-days and 56-days test; increased $9.77 \%$ comparing the 56-days and 84-days test; and reduced again 8.38\% comparing the 84 -days and 112 -days test. Pearson and Spearman correlations ( 0.851 and $0.877 ; P<0.001)$ between 56-days and 112-days test were not sufficient to determine the reduction of the test for 56 days, although relative variance increase did not exceed $2 \%$ in periods higher than 56 days.

Thus, a 84-days test should be recommended to obtain accuracy measure of daily weight gain. Pearson and Spearman correlations $(0.90 ; P<0.001)$ supported this finding (Table 2). Archer et al. (1997) determined the effect of shortened test period on heritability and reported higher results for 56 -d test $(0.38 \pm 0.11)$ than 112 -d test $(0.27 \pm 0.10)$, recommending a 70 -days test. This result can be explained for the differences in weighing periods, 28 days for this and 7 days for their study. Reducing this interval, an intermediary test period from 56 to $84 \mathrm{~d}$ could be determined.

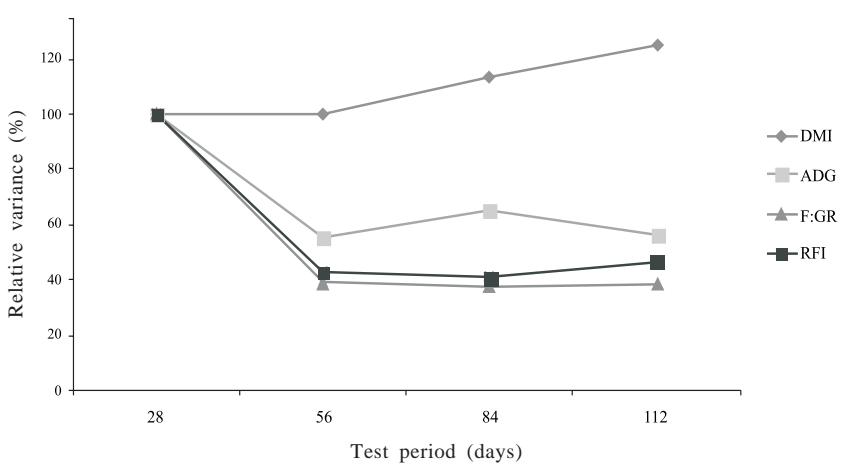

DMI = dry matter intake; ADG = average daily gain; F:GR = feed:gain ratio; $\mathrm{RFI}=$ residual feed intake.

Figure 1 - Changes on relative variance of performance measurements in Nellore cattle by reducing test period. 


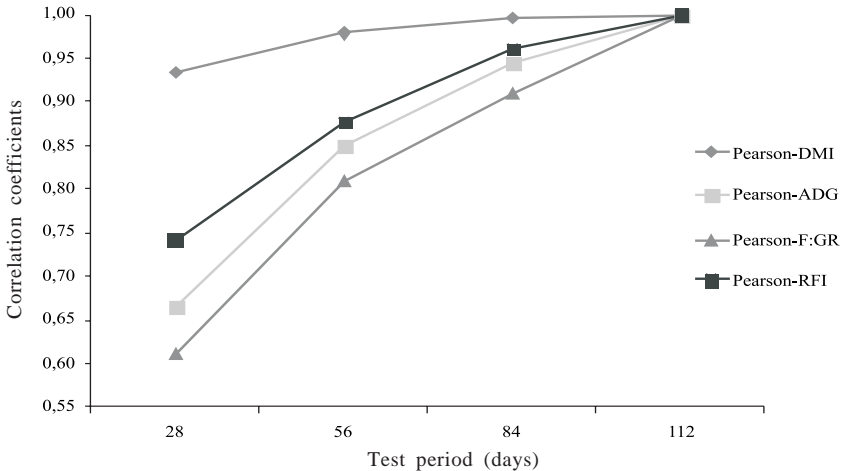

$\mathrm{DMI}=$ dry matter intake; $\mathrm{ADG}=$ average daily gain; $\mathrm{F}: \mathrm{GR}$ = feed:gain ratio; RFI = residual feed intake.

Figure 2 - Pearson coeeficients of correlation among shortned (28, 56 and 84 days) and full (112 days) test period for performance measures in Nellore cattle.

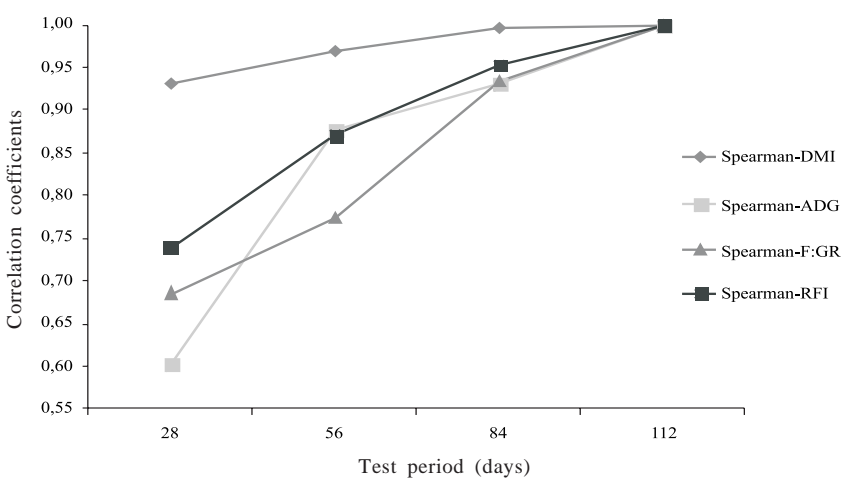

$\mathrm{DMI}=$ dry matter intake; $\mathrm{ADG}=$ average daily gain; $\mathrm{F}: \mathrm{GR}$ = feed:gain ratio; RFI = residual feed intake.

Figure 3 - Spearman coefficients of correlation among shortned (28, 56 and 84 days) and full (112 days) test periods for performance measures in Nellore cattle.

Variance for dry matter intake decreased $0.18 \%$ (from 28 to 56 days), increased $13.67 \%$ (from 56 to 84 days) and increased $11.22 \%$ (from 84 to 112 days). This might be attributed to the increase of dry matter intake due to the increase of body weight gain over the test period. As the variance for dry matter intake did not stabilized over the test period, Pearson and Spearman rank correlations were used to determine optimum test period. Pearson and Spearman rank correlations were higher than $0.93(P<0.001)$ over the test period (Table 2). This indicates that a 28-days test duration should be sufficient to obtain a relatively accurate measure of dry matter intake, nearly to the results (35-days test) reported by Archer et al. (1997) e Wang et al. (2006).

Relative variance for feed:gain ratio and residual feed intake were lesser than $2 \%$ (1.20 and 2.40\%) from 56 to 84 days and were negative ( -0.20 and $-6.04 \%$ ) from 84 to 112 days, respectively. In addition, Pearson and Spearman rank correlations were greater than $0.9(P<0.001)$ from 84
Table 2 - Criteria used to determine the optimum test period for performance measures of Nellore cattle ${ }^{1}$

\begin{tabular}{|c|c|c|c|c|}
\hline \multirow[b]{2}{*}{ Criterium $^{2}$} & \multicolumn{4}{|c|}{ Days of test } \\
\hline & 28 & 56 & 84 & 112 \\
\hline & & \multicolumn{3}{|c|}{ Average daily gain, kg/day } \\
\hline Variance & 0.022 & 0.012 & 0.014 & 0.012 \\
\hline Relative variance & & 44.90 & -9.77 & 8.38 \\
\hline Pearson & 0.665 & 0.851 & 0.945 & 1.000 \\
\hline \multirow[t]{2}{*}{ Spearman } & 0.603 & 0.877 & 0.931 & 1.000 \\
\hline & & \multicolumn{3}{|c|}{ Dry matter intake, kg/day } \\
\hline Variance & 0.451 & 0.450 & 0.512 & 0.562 \\
\hline Relative variance & & 0.18 & -13.67 & -11.22 \\
\hline Pearson & 0.933 & 0.979 & 0.996 & 1.000 \\
\hline Spearman & 0.931 & 0.969 & 0.996 & 1.000 \\
\hline & \multicolumn{4}{|c|}{ Feed:gain ratio, DM intake:average daily gair } \\
\hline Variance & 1.990 & 0.776 & 0.755 & 0.759 \\
\hline Relative variance & & 61.01 & 1.20 & -0.20 \\
\hline Pearson & 0.610 & 0.809 & 0.909 & 1.000 \\
\hline \multirow[t]{2}{*}{ Spearman } & 0.685 & 0.774 & 0.934 & 1.000 \\
\hline & & \multicolumn{3}{|c|}{ Residual feed intake, kg/day } \\
\hline Variance & 0.201 & 0.087 & 0.082 & 0.094 \\
\hline Relative variance & & 56.77 & 2.40 & -6.04 \\
\hline Pearson & 0.742 & 0.877 & 0.960 & 1.000 \\
\hline Spearman & 0.740 & 0.870 & 0.954 & 1.000 \\
\hline
\end{tabular}

to 112 days (Table 2) for both traits. Dry matter intake and average daily gain are needed to calculate feed efficiency, feed:gain ratio and residual feed intake. Thus, changes in variance were affected by trend of both traits.

Although a 28 days test is sufficient for evaluating dry matter intake, 84days of test is needed to maintain accuracy on measures of feed:gain ratio and residual feed intake. This proves that duration of dry matter intake measure is not determinant for the efficiency measurements. The results of the current study are similar to those obtained by Archer $\&$ Bergh (2000), that recommended a 84 days test for both traits, but they differed from those recommended by Wang et al. (2006): 42 days of evaluation for feed:gain ratio and 63 days for residual feed intake. Pearson and Spearman rank correlations for residual feed intake at 56 days were similar in the current study ( 0.877 and $0.870 ; P<0.001)$ to those observed by Wang et al. (2006) for the same period (0.898 and 0.899; $P<0.01)$ respectively. Thus, although the ideal test duration to evaluate residual feed intake is 84 days, a shortened period (56 and 84 days) can be used when economical factors are limiting, with very little loss in accuracy (2\% in variance).

Among 11 Elite animals classified on the full test period (112 days), just one of them did not have the same classification in the test shortened to 84 days and four in the test shortened to 56 days (Table 3). 
Animals that lost Elite classification in shortened test periods ( 84 and 56 days) were bellow the $7^{\text {th }}$ position of the ranking by IP378 in the full test period (112 days). These findings indicate that shortened test periods of 84 or 56 days did not discard the animals selected as potential sires, classified by the criteria adopted by the breeding project, because just three sires are yearly chosen for Elite herd. In addition, among the $7^{\text {th }}$ first ranked animals (Elite) would also be four ones for reserve for eventual replacement. Examining Spearman coefficients of correlations for IP378 among full (112 days) and shortened (56 and 84 days) period test, $0.97 ; P<0.001$, it appears that the test duration corroborates the results found for average daily gain.

Effects of test duration (56, 84 and 112 days) on feeding performance test index (IPGP) and standardized weight at 378 days of age index were similar (Table 4). This can be a reason why just one animal, among nine classified as Elite in the total period (112 days) was not classified as Elite in the 84 days test and three were not classified in the 56 days test. Another two animals that were not classified as Elite in the full test period (112 days) reached the index to be classified as Elite in both shortened periods (56 and 84 days). Spearman rank correlation for feeding performance

Table 3 - Index of standardized weight at 378 days of age over three test periods for feeding performance test in Nellore cattle

\begin{tabular}{|c|c|c|c|c|c|c|c|c|c|c|c|c|}
\hline \multirow[b]{2}{*}{$\begin{array}{l}\text { Animal/ } \\
n^{\circ} \text { pen* }\end{array}$} & \multicolumn{4}{|c|}{56 days } & \multicolumn{4}{|c|}{84 days } & \multicolumn{4}{|c|}{112 days } \\
\hline & $\begin{array}{c}\text { BW378 } \\
\text { (kg) }\end{array}$ & IP378 & Category & $\begin{array}{c}\text { Overall } \\
\text { ranking } \\
\text { by IP378 }\end{array}$ & $\begin{array}{c}\text { BW378 } \\
\text { (kg) }\end{array}$ & IP378 & Category & $\begin{array}{c}\text { Overall } \\
\text { ranking } \\
\text { by IP378 }\end{array}$ & $\begin{array}{c}\text { BW378 } \\
\text { (kg) }\end{array}$ & IP378 & Category & $\begin{array}{c}\text { Overall } \\
\text { ranking } \\
\text { by IP378 }\end{array}$ \\
\hline 20 & 413 & 137 & Elite & 1 & 423 & 137 & Elite & 1 & 416 & 135 & Elite & 1 \\
\hline 51 & 383 & 127 & Elite & 3 & 400 & 130 & Elite & 2 & 393 & 128 & Elite & 2 \\
\hline 40 & 384 & 127 & Elite & 2 & 390 & 127 & Elite & 3 & 389 & 126 & Elite & 3 \\
\hline 15 & 353 & 117 & Elite & 6 & 362 & 117 & Elite & 5 & 367 & 119 & Elite & 4 \\
\hline 60 & 369 & 122 & Elite & 4 & 368 & 119 & Elite & 4 & 364 & 118 & Elite & 5 \\
\hline 19 & 364 & 121 & Elite & 5 & 358 & 116 & Elite & 6 & 358 & 116 & Elite & 6 \\
\hline 6 & 351 & 116 & Elite & 7 & 352 & 114 & Elite & 9 & 354 & 115 & Elite & 7 \\
\hline 1 & 334 & 111 & NS & 11 & 354 & 115 & Elite & 8 & 352 & 114 & Elite & 8 \\
\hline 56 & 336 & 111 & NS & 10 & 351 & 114 & Elite & 10 & 351 & 114 & Elite & 9 \\
\hline 55 & 329 & 109 & NS & 12 & 345 & 112 & NS & 11 & 350 & 114 & Elite & 10 \\
\hline 22 & 339 & 112 & NS & 9 & 355 & 115 & Elite & 7 & 349 & 113 & Elite & 11 \\
\hline 29 & 344 & 114 & Elite & 8 & 341 & 110 & NS & 12 & 338 & 110 & NS & 12 \\
\hline Spearman & IP378 & 0.975 & & & & 0.986 & & & & - & & \\
\hline
\end{tabular}

Table 4 - Feeding performance test of Nellore cattle over three test periods

\begin{tabular}{|c|c|c|c|c|c|c|}
\hline \multirow[b]{2}{*}{ Animal/pen* } & \multicolumn{2}{|c|}{56 days } & \multicolumn{2}{|c|}{84 days } & \multicolumn{2}{|c|}{112 days } \\
\hline & IPGP & Category & IPGP & Category & IPGP & Category \\
\hline 20 & 141 & Elite & 142 & Elite & 138 & Elite \\
\hline 1 & 120 & Elite & 127 & Elite & 126 & Elite \\
\hline 51 & 123 & Elite & 128 & Elite & 124 & Elite \\
\hline 40 & 124 & Elite & 123 & Elite & 123 & Elite \\
\hline 55 & 114 & NS & 119 & Elite & 122 & Elite \\
\hline 25 & 124 & Elite & 122 & Elite & 119 & Elite \\
\hline 19 & 124 & Elite & 116 & Elite & 117 & Elite \\
\hline 15 & 113 & NS & 114 & NS & 117 & Elite \\
\hline 56 & 111 & NS & 115 & Elite & 116 & Elite \\
\hline 60 & 121 & Elite & 116 & Elite & 114 & NS \\
\hline 44 & 114 & NS & 118 & Elite & 113 & NS \\
\hline 36 & 115 & Elite & 108 & NS & 107 & NS \\
\hline
\end{tabular}


test in full (112 days) and shortened (56 and 84 days) test periods were higher than $0.94(P<0.001)$.

The feeding performance test adopted by Instituto de Zootecnia (Centro APTA Bovinos de Corte-Sertãozinho) can be shortened to 140 days, being the 56 initial days for adaptation and the 84 final days for data collection. Reducing 28 days of the test duration could reduce $21 \%$ of the costs associated with feeding. Longer tests duration result in greater feed intake by evaluation period (Figure 4), because heavier animals consume more feed to achieve requirement for growth. Reducing 28 days of test also results in an economy of $17 \%$ in costs with labor, equipments and facilities.

Data collection costs for feed intake (used to calculate feed efficiency traits) is high and becomes antieconomical for some species, when feed intake of all potentially selectable animals is evaluated. However Arthur \& Herd (2004) pointed that, if the selection is performed in 2 phases, the method becomes more appropriated. This can be confirmed by the inclusion of feed efficiency in the analysis of breeding and genetic programs, which generate benefits higher than those of the programs with no feed efficiency in the analysis. All potentially selected animals first are evaluated for growth traits during the selection phase. After this phase, the individuals strategically selected are submitted to the feed efficiency evaluation.

Reducing 28 days in the test duration can increase the number of animals tested or reduce costs associated with the test and provide in the second phase a selection for feed efficiency traits with the animals selected as Elite in the first phase.

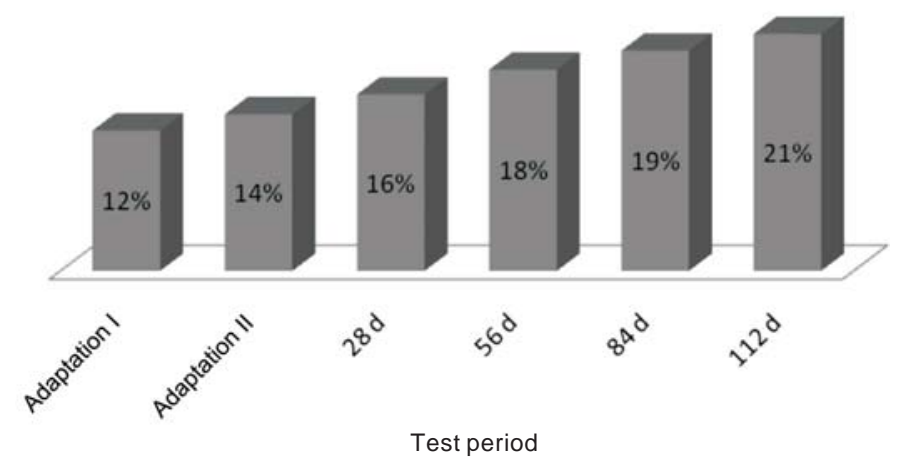

Figure 4 - Amount of food consumed in each evaluation period in relation to the total period.

\section{Conclusions}

Test duration for average daily gain, dry matter intake, feed:gain ratio and residual feed intake can be shortened to 84, 28, 84 and 84 days, respectively, without reducing significantly the reliability of measurements for Nellore cattle fed in individual pens.

\section{References}

ASSOCIATION OF ANALYTICAL CHEMISTRY - AOAC. Official Methods of Analysis. 16.ed. Arlington: AOAC International, 1995. 1025p.

ARCHER, J.A.; ARTHUR, P.F.; HERD, R.M. et al. Optimum postweaning test for measurement of growth rate, feed intake and feed efficiency in British breed cattle. Journal of Animal Science, v.75, n.8, p.2024-2032, 1997.
ARCHER, J.A.; BERGH, L. Duration of performance tests for growth rate, feed intake and feed efficiency in four biological types of beef cattle. Livestock Production Science, v.65, n.1, p.47-55, 2000

ARTHUR, P.F.; HERD, R.M. Efficiency of feed utilization by livestock - Implications and benefits of genetic improvement. Canadian Journal of Animal Science, v.85, n.3, p.281-290, 2005.

ARTHUR, P.F.; BARCHIA, I.M.; GILES, L.R. Optimum duration of performance tests for evaluating growing pigs for growth and feed efficiency traits

Journal of Animal Science, v.86, n.5, p.1096-1105, 2008.

BROWN JR., A.H.; CHEWNING, J.J.; JOHNSON, Z.B. et al. Effects of 84-, 112- and 140-day postweaning feedlot performance tests for beef bulls. Journal of Animal Science, v.69, n.2, p.451-461, 1991.

HERD, R.M.; ARCHER, J.A.; ARTHUR, P.F. Reducing the cost of beef production through genetic improvement in residual feed intake: Opportunity and challenges to application. Journal of Animal Science, v.81, n.1, p.9-17, 2003.

KOCH, R.M.; SWIGER, L.A.; CHAMBERS, D. et al. Efficiency of feed use in beef cattle. Journal of Animal Science, v.22, n.2, p.486-494, 1963. 
MACHADO NETO, O.R.; LADEIRA, M.M.; GONÇALVES, T.M. et al. Feed intake and prediction assessments using the NRC, CNCPS and BR-CORTE systems in Nellore and Red Norte steers finished in feedlot. Revista Brasileira de Zootecnia, v.39, n.2, p.394-401, 2010.

NATIONAL RESEARCH COUNCIL - NRC. Nutrients requeriments of beef cattle. 7.ed. Washington, D.C.: 1996. 244p.

RAZOOK, A.G.; MERCADANTE; M.E.Z. Requisitos de qualidade na bovinocultura de corte. In: SIMPÓSIO SOBRE BOVinocultura DE CORTE, 6., 2007, Piracicaba. Anais... Piracicaba p.93-144, 2007.

RAZOOK, A.G.; FIGUEIREDO, L.A.; CYRILLO, J.N.S.G. et al. Prova de ganho de peso: normas adotadas pela Estação Experimental de Zootecnia de Sertãozinho. Nova Odessa: Instituto de Zootecnia. 1997. 33p. (Boletim Técnico, 40).
SNOWDER, G.D.; VAN VLECK, L.D. Effect of duration of performance test on variance component estimates for lamb growth rate. Journal of Animal Science, v.80, n.8, p.2078-2084, 2002.

STATISTICAL ANALYSIS SYSTEM - SAS. SAS/STAT User's guide. Cary: Statistical Analysis System Institute, 1999. (CD-ROM).

STEEL, R.G.D.; TORRIE, J.H.; DICKEY, D.A. Principles and procedures of statistics: a biometrical approach. 3.ed. New York: McGraw-Hill Companies, 1997. 666p.

WANG, Z.; NKRUMAH, J.D.; LI, C. et al. Test duration for growth, feed intake, and feed efficiency in beef cattle using the GrowSafe System. Journal of Animal Science, v.84, n.9, p.2289-2298, 2006. 